\title{
Homeobox Protein Hox-D13
}

National Cancer Institute

\section{Source}

National Cancer Institute. Homeobox Protein Hox-D13. NCI Thesaurus. Code C97585.

Homeobox protein Hox-D13 (343 aa, $~ 36 \mathrm{kDa}$ ) is encoded by the human HOXD13 gene.

This protein plays a role in transcriptional modulation that mediates limb and appendage formation. 